\title{
Okul Öncesi Öğretmenliği Öğretim Programında Yer Alan Seçmeli Müze Eğitimi Dersinin Gerekliliğine İlişkin Öğrenci Görüşserinin İncelenmesi
}

\author{
Erdem Erem ${ }^{1}$
}

\begin{tabular}{ll}
\hline \multicolumn{2}{l}{ Makale Bilgisi } \\
\hline DOI: 10.21612/yader.2017.011 \\
\hline \multicolumn{2}{l}{ Makale Geçmişi } \\
Geliş tarihi & 14.04 .2017 \\
Kabul & 20.10 .2017
\end{tabular}

Anahtar Sözcükler

Sanat ĕgitimi

Müzede ĕgitim/müze e ğitimi

Okul öncesi ögrretmen adayı

Eğitimde yaratıcı drama

\begin{abstract}
Öz
Sanat eğitimi özelinde "Müze Eğitimi" kavramı ülkemizde son yıllarda önem kazanmaya ve örgün eğitim kurumlarında klasik gezi hareketliliği dışında tanımlanmaya başlanmıştır. Bunun yanında gezi hareketliliği klasik gez, gör, soru, cevapla anlayışından çıkarak, gez, gör, yaşa, içselleştir ve yeni bağlantılar kur başliklarına doğru everilmektedir.

Bu araştırma, okul öncesi ögretmenliği programının sekizinci yarıyllındaki seçmeli derslerden biri olan Müze Ĕgitimi dersini alan okul öncesi ögretmen adaylarının, programlarında yer alan seçmeli müze eğitimi dersinin programdaki gerekliliğine ilişkin görüşlerinin neler olduğunu açı̆̆a çıkarma amacını taşıyan betimsel bir çalışmadır. Ĕgitim alanında var olan sorunları açı̆̆a çıkararak betimleme yapılmaksızın derinlikli çalışmalara geçmek çoğu zaman olanaklı değildir. Betimsel nitelik taşıyan bu çalışmada veri toplama aracı olarak açık uçlu sorularla oluşturulmuş yarı yapılandırılmış görüşme formu kullanılmıştır. Araştırma grubunu 2012 yll bahar döneminde seçmeli "Müze Eğitimi”" dersini seçen ve Ege Üniversitesi Ĕ̆itim Fakültesi İlkögrretim Bölümü okul öncesi ögrretmenliği lisans programı 4.sını öğrencisi 25 ögretmen adayı olușturmaktadır. Veri toplama sürecinde yarı yapılandırılmış açık uçlu görüşme sorularıla bireysel görüşmeler yapılmıştır. Bu görüşmeler sonucunda elde edilen veriler betimsel analizle çözümlenmiştir. Veri analizi sonucunda ulaşılan kodlar ve temalar doğrultusunda seçmeli olan dersin zorunlu olup olmaması gerektiği konusu öğretmen adaylarının bakış açısına göre ortaya konmaya çalışılmıştır.
\end{abstract}

\section{Exploring Views of Prospective Early Childhood Teachers on The Importance of The Elective Museum Education Course in The Early Childhood Education Curriculum}

\begin{tabular}{lr} 
Article Info \\
\hline DOI: $10.21612 /$ yader.2017.011 \\
\hline Article History & \\
Received & 14.04 .2017 \\
Accepted & 20.10 .2017
\end{tabular}

Keywords

Arts education

Museum education,

Prospective early childhood teachers

Creative drama in education

\begin{abstract}
The museum education methodology has recently gained wide-spread use among formal education institutions. The museum education was defined outside the boundaries of classical field trips. Furthermore field trips has gone through a reformation moving away from the classical tour-observe-question-answer drills to a broader set of constructivist activities involving: touring, observing, experiencing, getting involved and establishing new connections.

This descriptive study attempted to investigate the views of prospective Early Childhood Teachers regarding the importance of the elective Museum Education course for the program curriculum. Descriptive studies are a priori requirements before in depth intervention research. Research data were collected through one-onone semi-structured interviews with the participants. The participants of the study were 25 seniors studying at Ege University College of Education's Early Childhood Education Program. All participants were enrolled in elective Museum Education course and volunteered to take part in the research. Data were descriptively analyzed. In light of the codes and themes emerging from the data, the participants' views regarding the course was portrayed.
\end{abstract}




\section{Giriş}

Müzeler toplumun ve kültürün geçmişten bize bıraktıklarını biriktiren, koruma altına alan, araştırmaya ve halkın eğitimine olanak sağlayan kuruluşlardır. Çağdaş ülkelerde müzelere bakıldığında müzeler birer eğitim ihtiyacı olarak karşımıza çıkmaktadır. Ancak ilk kurulduklarında böyle bir işlevlerinin olmadı̆̆ını, eğitimin yalnızca 20. yüzyıl ortalarından itibaren kendine müzelerde yer bulmaya başladığını görmekteyiz. Ancak bu yıllarda müze misafirlerinin müzeleri gezerken eğitim yoluyla müzeyi alımlamaları önemli bir işlev olarak kabul edilmeye başlanmıştır. Bunun sonucunda ise "müze eğitimi/müze pedagojisi" bir disiplin olarak bilim alanında kendine yer bulmuşstur (Akmehmet Tezcan \& Ödekan, 2006).

20. yüzyılla beraber obje odaklı, sergileme, saklama amaçlı müze anlayışı, İkinci Dünya Savaşı sonrası değişikliğe uğramıştır. Düşünce dünyasındaki ve sanatta savaş sonrası değişen değişimler müzecilik anlayışına, insanın yalnız izleyen değil müzeyle bağ kurabilen bireye dönüşmesi olarak yansımıştır. Bu değişimle beraber kurumsal olarak müzeler de insana dönük çalışmalara, gezici ve süreli sergilere önem vermeye başlamıştır. Müzeler bulunduğu toplum ve kültürü geliştirmeye dönük olarak eğitime katkıda bulunmaları gerektiğini fark etmişlerdir.

Çağdaş müzeler, misafirin doğrudan sergiyi tasarlayan kişinin fikrini algıladığı değil alımlayan olarak müzeyle birleştiği, bütünleştiği hatta bireysel ihtiyaçlara göre konuların ve eğitim programlarının belirlendiği bir gezi, gözlem, eğitim alanı haline gelmektedir(Akmehmet Tezcan \& Ödekan, 2006).

Görülmektedir ki günümüzde değişen müzecilik anlayışı, müzelerin ülkemizde şimdiye kadar olan fiili görevlerinin yeniden gözden geçirilmesi gerekliliğini ortaya koymaktadır. Özellikle son elli yılda müzeler, sadece değerli nesneleri sergileme anlayışının yanında, müzede eğitime, yaşantı yollu öğrenmelere ve özellikle sanat eğitimine olanak sağlayan mekânlar olmaya başlamışlardır. $\mathrm{Bu}$ bağlamda; sanat eğitimi kavramını açmakta fayda görülmektedir. San (1985) sanat eğitimini, özellikle yetişen kuşaklar başta olmak üzere, tüm topluma yönelen ve sanatı, sanatsallı̆̆ı, devingen ve değişkenliği içinde kavratan, yaşamsal değerini belirleyen ve yaratıcıllğı sanat ve düşün alanında geliştirme amacı taşıyan eğitsel programların bütünü olarak tanımlamaktadır. Bu tanıma ve müzelerin günümüz dünyasında üstlendiği çoklu görevlere bakıldığında, gerek sanat eğitimi merkezi gerekse sanat eserlerini koruma mekânı olarak müzelerin toplum hayatı içinde geniş ölçüde var olduğu yadsinamaz durumdadir.

Akmehmet (2001), müzelerin işlevlerinden bahsederken okulların kuramsal bilgi aktarımıyla sınırlı kaldığını ve bu sınırlılı̆̆ın öğrenenlerde bilginin yaşantıyla bağlantısını zayıflattığını belirtmiştir. Bu nedenle müzelerin okulda edinilen öğrenme yaşantılarının zenginleşmesine katkıda bulunan mekânlar olduğunu dile getirmektedir. Müzeler, sosyal bilimlerden fen bilimlerine kadar tüm alanlarda somut örnekler barındırmakta ve aynı zamanda öğrenene bağlantı kurma olanağı sağlamaktadır. Bir başka deyişle müzeler, okulların işlevlerini de barındırmakta hatta öğretim programları için alternatif öğrenme alanları olarak karşımıza çıkmaktadır. Yani günümüzde, müzelerle okullar arasındaki işlevsel benzerliğin giderek arttığı söylenebilir. Ancak müze derken bilinen okul binası formatının dışında ancak okul kadar hatta belki de daha işlevsel, bir mekândan söz edilmektedir. 
Eğitimde yeni yaklaşımların gün geçtikçe merkeze öğreneni aldığı, okul dışı öğrenmelerin altının çizildiği, farklı öğrenme yaklaşımlarının denendiği çağımızda, müze ortamlarında farklı programların uygulanabilmesi için gerçek sanat nesnelerinin gözlemlenmesi, hatta sanat nesnelerinin reprodüksiyonlarının yapılması, öykülerinin öğrenilmesi ve canlandırılması gibi yaşantılarla sanatın da elbette belli bir programı izlemesi gerektiği açıktır. Adıgüzel'in (2006) de belirttiği gibi bir eğitim programı, yaşantılar açısından öğrenene okulda ve okul dişında planlanmış etkinlikler yoluyla sağlanan öğrenme yaşantılarıdır. Yaratıcı drama ise, "sahip olduğu özellikleri, çok yönlü işlevselliği nedeniyle her türlü ögrenme ortamlarında, sosyal yeterliğin kazanılmasında ve özellikle de yaşantılara dayalı ögrenmeyi gerçekleştirmede etkili olabilecek bir yöntem ve disiplindir (alandır)'(Adıü̈zel, 2006) tanımlaması ile öğrenme yaşantılarının oluşturulmasına hizmet ektedir. Alanyazında müzelerin ve galerilerin, özellikle sanat eğitimine ve yaratıcı drama yöntemi uygulamalarına olanak veren öğrenme deneyimleri için önemli yerler olduğu vurgulanmaktadır (Abacı, 2003; Abac1, 2008; Adıgüzel, 2004; Adıgüzel, 2006a, 2006b; Eğitmen, 1995; Eğitmen, 2007; Erem, 2015; Okvuran, 2010; Şahin, 2007; Terwiel, 2007; San, 2008).

Türkiye'de eğitime ilişkin sorunların, okul öncesi eğitim aşamasından başlayıp üniversite süreci boyunca da devam ettiği söylenebilir. Ancak, ilk ve ortaöğretimde çocukların ve gençlerin karşı karşıya kaldığ 1 eğitimle ilgili sorunlar çok önemlidir. Öğrenme yaşantılarının canlı tutulması için öğretim yöntem ve teknikleri açısından farklı uygulamalar yapmak ve eğitim ortamını çeşitlendirmek gerekmektedir. Ancak unutulmamalıdır ki nitelikli bir eğitim için etkili olarak hazırlanmış öğretim programları yanında bu programları uygulama sorumluluğunu taşıyan bilgili, becerikli ve duyarlı öğretmenlere ihtiyaç vardır. Bu açıdan bakıldığında öğretmen adaylarının hizmet öncesinde sözü edilen göreve hazır olarak yetişmiş olmaları gerekmektedir. Öğretmen adaylarının üniversite eğitimi sürecinde öğrenmelerine rehber olunmalı ve meslek yaşantılarında öğretimi etkin gerçekleştirebilmelerine destek olacak çalışmalar üniversite eğitim öğretim yaşantılarının içine dâhil edilmelidir.

Okul öncesi programına ve uygulama esaslarına bakıldığında tüm kavramlar, konu başlıkları ve kazanımlar yaşantı yoluyla öğrenmeye olanak sağlayacak niteliktedir. Özellikle sınıf dışı eğitimler açısından bakıldığında okul öncesinde somut işlemler döneminde olan öğrencilerin eğitim-öğretimi için müze, galeri vb. mekanlar öğretmenin somutlaştırma ihtiyacını karşılayabilir niteliktedir. Ancak YÖK'ün eğitim fakültelerinde zorunlu olarak uyguladığ 1 okul öncesi öğretmenliği programında bu konuda bir ders ya da herhangi bir dersin içeriği bulunmamaktadır.

$\mathrm{Bu}$ bağlamda, eğitim fakülteleri için uygulamada olan programda seçmeli derslere bir alternatif olarak Ege Üniversitesi tarafından 14 Nisan 2009' da yapılan başvuruyla 2010-2011 öğretim yılından itibaren "Seçmeli Müze Eğitimi” dersinin onayı alınarak okul öncesi öğretmenliği, sınıf öğretmenliği ve sosyal bilgiler öğretmenliği ana bilim dallarında uygulamaya geçirilmiştir.

Alan yazınında belirtilen durumlar göz önünde bulundurularak araştırmanın problem tümcesi; seçmeli olarak yürütülen müze eğitimi dersinin zorunlu bir ders olmasının gerekliliği konusunda öğretmen adaylarının ne düşündüğünü ortaya koymak ve bu konudaki tartışmalara katkı sağlamak olarak belirlenmiştir.

Araştırmanın amacı ise; okul öncesi öğretmen adaylarının "Seçmeli Müze Eğitimi” dersinin gerekliliğine ilişkin görüşlerinin neler olduğunu belirlemektir. Bu amaç çerçevesinde araştırmacı tarafından, farklı ortamlarda (sınıf, müze, galeri, sergi) kuramsal ve uygulamaya dayalı dersler/ 
atölye çalışmaları yürütülmüştür. Tüm süreç boyunca çağdaş müze eğitimi yaklaşımlarından (eğitimde yaratıcı drama, oryantiring spor deseni, bilmece, resim, heykel, röportaj vb.) etkinlik temelli öğrenmelerden bir kolaj (seçki) yapılarak öğretmen adaylarının müzede/galeride vb. sınıf dış1/informal ortamlarda öğretimi nasıl planlayacakları öğretilmeye çalışılmıştır.

\section{Yöntem}

Bu bölümde araştırmanın modeline, çalışma grubuna, veri toplama araç ve tekniklerine, veri toplama sürecine ve verilerin analiz edilmesine ilişkin bilgilere yer verilmiştir.

\section{Araştırma Modeli}

Müze Eğitimi dersi, okul öncesi öğretmenliği programının sekizinci yarıyılında yer alan seçmeli derslerden biridir. Bu araştırma, okul öncesi öğretmeni adaylarının Müze Eğitimi dersinin gerekliliğine ilişkin görüşlerini incelemeyi amaçlayan betimsel bir çalışmadır. Betimsel çalışmalar yaşayanların, yaşananların ne olduğunun betimlenip açıklanarak ortaya konulması olarak ele alınabilir. Betimsel çalışmalar bireylerin sözü edilen olguya ilişkin duruş, görüş ve davranışlarını açığa çıkarma amacına dayalı olarak yürütülen çalışmalardır (Creswell, 2013). Eğitim alanında var olan sorunları açığa çıkararak betimleme yapılmaksızın derinlikli çalışmalara geçmek çoğu zaman olanaklı değildir.

Bu araştırmada araştırılan olgu sürmektedir, yani yaşamaktadır. Bu bakış açısıyla bakıldığında betimsel çalışma için uygun ortam söz konusudur. Diğer yandan betimsel çalışmanın alt araştırma türleri vardır. Bunlar; kitlesel araştırma, boylamsal araştırma ve geçmişe dönük araştırmalardır. $\mathrm{Bu}$ türlerden yapılan araştırma için en uygun olanı ise geçmişe dönük araştırma modeli olarak görülmektedir.

\section{Çalışma Grubu}

2011-2012 öğretim y1lı bahar döneminde seçmeli Müze Eğitimi dersini alan 25 öğretmen adayının tamamı çalışma grubunu oluşturmaktadır. Katılımcıların yirmisi kadın, beşi erkektir. Katılımcılar Müze Eğitimi dersini gönüllü olarak seçen bireylerdir. Bu dersin seçimine yönelik başlangıçta adaylara hiçbir yönlendirme ve bilgilendirme yapılmamıştır. Toplam 25 katılımcının yaş ortalaması 22,2'dir. Katılımcıların önceki dönemlerde aldıkları derslere ilişkin bilgiler vermek, dersin içeriğinde kullanılan yöntem ve teknikler konusunda hazır bulunuşlukları hakkında bir öngörü sağlayacaktır. Katılımcıların tamamı ders içerisinde geçen eğitimde yaratıcı drama yöntemini dördüncü dönemde yer alan "Drama" dersinde, beşinci dönemlerinde yer alan "Beden Eğitimi ve Oyun Öğretimi” dersinde de oyun ve kazanımlarını deneyimleyerek bilgi sahibi olmuşlardır. Ancak bu dersler dışında çalışmada yer alan bazı teknikleri ilk defa bu ders kapsamında deneyimlemişlerdir. Bunun dışında katılımcıların daimi ikamet ettikleri yerler açısından bakıldığında ise 25 katılımcının her biri farklı illerde ikamet etmek koşuluyla, 7 katılımcı(kadın) büyük şehir, üç katılımcı(kadın) İzmir'de ailesiyle beraber kalmaktadır. Çalışmaya dahil olan diğer katılımcılar(15 katılımcı-10K,5E-) ise ülkenin farklı taşra/küçük şehir yerleşimlerinde ikamet etmektedir.

\section{Veri Toplama Aracı}

Betimsel nitelik taşıyan bu çalışmada verilerin toplanması sürecinde, nitel veri toplama tekniklerinden olan görüşme işe koşulmuştur. Temelde görüşmenin amaçlı bir sohbet olduğu ve 
genellikle de iki kişi arasında gerçekleştiği söylenebilir (Uzuner, 1999). Görüşme tekniği kapsamında yapılandırılmış görüşme, yarı yapılandırılmış görüşme ve yapılandırılmamış görüşmelerden söz edilebilir (Karasar, 1999). Bu çalışmada, yarı-yapılandırılmış görüşme formları kullanılmıştır.

$\mathrm{Bu}$ araştırmada, katılımcıların müze eğitimi dersinin gerekliliğine ilişkin görüşlerinin toplanması amacıyla bireysel görüşmeler yapılmıştır. Bu görüşmelerde kullanılan yarı yapılandırılmış görüşme formlarının hazırlanmasında aşağıdaki yol izlenmiştir.

1. Konu ile ilgili ayrıntılı literatür taraması yapılmıştır.

2. Araştırmanın ana problem durumu oluşturulmuştur.

3. Buna göre İlköğretim Bölümü(Temel Eğitim) okul öncesi öğretmenliği öğretmen adaylarının müze gezilerinde, etkinliklerinde önceden yaşadıkları olası eğitim olanakları ve eğitim koşulları belirlenmiştir.

4. Müze eğitimi ve kullanılan tekniklerle ilgili yapılan araştırmalarda kullanılan sorular incelenmiştir.

5. Konuya ilişkin katılımcıların hazır bulunuşlukları göz önünde bulundurularak öğretim durumlarını, araştırmanın problemlerine ve öğretim ilke, yöntemlerine uygun olarak irdeleyebilecekleri sorular belirlenmiştir.

6. Görüşme formu için 17 tane açık uçlu soru hazırlanmıştır. Görüşme formu seçmeli müze eğitimi dersinin tanımlanmasını, diğer derslere göre mevcut durumunu, sürecin olumlu ve olumsuz yönlerini, ders içeriği/ölçme değerlendirmesini, dersin işleyişi s1rasında öğretmen adaylarının karşılaştığı durumlar sonrası oluşan düşünceleri almaya yönelik soruları içermektedir.

7. Görüşme formu uzman akademisyenlerin değerlendirmeleri doğrultusunda 13 soruya düşürülmüştür.

8. Sonrasında aynı dersi alan ancak araştırmanın sınırlılıklarına girmeyen beş öğretmen adayına pilot bir uygulama yapılmış ve tekrar uzman görüşü alınmıştır.

9. Yapılan pilot uygulamanın ardından son şekli verilen görüşme formu toplam 12 adet soru ve bu soruların içerisinde yer alan altı adet sonda sorudan oluşturulmuştur.

\section{Verilerin Toplanması}

Veriler yarı yapılandırılmış açık uçlu görüşme sorularıyla bireysel görüşmeler yapılarak toplanmıştır. Görüşme tekniği araştırmada sonuca ulaşmada önemli bir rol oynamıştır. Özellikle soru sorma sırasında bireylerin tepkilerine göre sorulara yön vermenin de çalışmaya önemli ölçüde katkı sağlayacağı düşünülmüştür. Özellikle Robson'ın (2015) belirttiği gibi anketlerin yapamadığını görüşme sırasında araştırmacı farklı veya ilgi çekici yanıtları sonda sorularla netleştirerek, katılımcılara görüşlerinin nedenini/bağlamını fark etme olanağı sunarak gerçekleştirebilmektedir.

Görüşme takvimi öğretmen adayları mezun olduktan sonra planlanmıştır. Bu nedenle öğretmen adaylarının tarafsız, etki altında kalmadan soruları cevaplamaları sağlanmış ve görüş belirtebilecek seviyede profesyonel fikirlere sahip oldukları varsayılmıştır.

Her bir katılımcı ile bireysel olarak etik anlaşma yapılarak görüşmeler araştırmacı tarafından gerçekleştirilmiştir. Görüşmeler izole edilmiş bir odada kayıt altına alınmış (video/ses) ve yaklaşık 30 ile 70 dakika arasında sürmüştür. Çalışmada sadece katılımcıların dersin gerekliliği ve zorunlu 
mu yoksa seçimlik mi olması gerektiği konusuna odaklanılmıştır. Bu nedenle görüşme dökümlerinin sadece gerekli bölümü araştırmaya dahil edilmiştir.

Ayrıca araştırmacı araştırma sürecinde süreci uygulayan ve görüşmeyi yapan kişi olarak da rol almıştır. Araştırmacı 11 yıldır müzede eğitim çalışmalarında uygulayıcı olarak çalışmıştır. Bunu yanında da altı yıllık öğretim elemanıdır. Dersin yürütücüsü olduğu için de derse objektif bakışını kaybetmemiş ve araştırmacı, eleştirel duruşunu da süreçte işe koşmuştur. Bu bağlamda hem katılımcılar açısından hem de araştırmacı açısından araştırma sürecinde araştırma kriterlerine uygun bir yaklaşım sergilenmiştir.

$\mathrm{Bu}$ çalışmada veriler süreç bittikten sonra toplandığı için geçmişe dönük bir betimsel çalışma modeli seçilmiştir. Çünkü Sönmez ve Alacapınar (2011), geçmişe dönük betimsel çalışmayı anlatırken, seçimlerden hemen sonra seçmenlerin, uzmanların, parti temsilcilerinin görüş ve önerilerini almaları örneğini vermişlerdir. Burada da bireylerin notların açıklanması gibi üzerlerinde bask1 yaratabilecek bir durumun etkisinden kurtulmalarından sonra görüş belirtmelerinin sürecin değerlendirilmesi bağlamında çalışmayı daha güvenilir kılabileceği düşünülmüştür. Özellikle tüm notların girilip öğrencilerin mezun duruma gelmelerinden sonra bu verilerin toplanması öğrencilerin not kaygısından dolayı samimi olmamaları durumunu bertaraf etmek için önemli bir durum olarak görülmekte ve betimsel yapıyı desteklemektedir.

\section{Verilerin Analizi}

Veriler betimsel analiz tekniğiyle çözümlenmiştir.

1. Ses kayıtları incelenerek, yazılı doküman haline getirilmiştir.

2. Yazılı hale getirilen ham bulguların üzerinde kod ve tema oluşturma çalışmaları yapılmıştır. Bu çalışmalarda katılımcıların ders hakkındaki görüşlerinin odak noktaları bulunarak betimsel analiz temellendirilmiştir.

3. Nitel araştırma yöntemleri konusunda yetkin iki uzman tarafindan kodlayıcılar arası güvenilirlik çalışması yapılarak tema ve kodların son haline ulaşılmıştır.

4. Verilerin analizi sürecinde betimsel bir yaklaşımla öğretmen adaylarının oluşturulan temalar altında sınıflandırılması ve özetlenmesi ile çalışma şekillendirilmiştir. Bunun için önce öğretmen adaylarının her bir soruya verdikleri yanıtlar alt alta getirilerek ve bu metin araştırmacı tarafından tekrar tekrar okunarak öğretmen adaylarının verdikleri cevaplardaki kategoriler belirlenmiş ve veriler böylece sınıflandırılmıştır.

5. Ayrıca bulgular bölümünde her görüşün kaç öğretmen adayı tarafindan paylaşıldığ 1 frekans(f) hesaplamalarıyla gösterilmiş ve öğretmen adaylarının bazı görüşlerine ait doğrudan cümlelere de yer verilmiştir. Özellikle katılımcıların söyledikleri tümcelerin doğrudan alıntılanmasının çalışmanın güvenilirliğini arttırdığı düşünülmektedir. Yıldırım ve Şimşek (2011) de veri kaynaklarından doğrudan alıntılar yapmanın çalışmanın güvenirliğini olumlu etkilediğini çeşitli araştırmacılar tarafından belirtildiğinin altını çizmektedir. 


\section{Bulgular}

$\mathrm{Bu}$ bölümde öğretmen adaylarının yarı yapılandırılmış görüşme formundaki açık uçlu sorulara vermiş oldukları yanıtlardan elde edilen bulgular sunulmuştur. Verilen yanıtlardan yola çıkılarak analizi yapılan ve frekans değerleri ile özetlenen veriler okuyucunun daha iyi anlayabilmesi için grafik haline getirilmiştir.

Çalışmanın yöntem bölümünde belirtilen görüşme formuyla tüm ders sürecini kapsayan verilerden bu çalışmanın sınırlılığı içinde sadece seçmeli müze eğitimi dersinin gerekliliğine yönelik öğretmen adayı görüşlerine yer verilmiştir. Diğer veriler çalışma kapsamı dışında bırakılarak çalışmanın problem durumu ve amacına uygun bir odak oluşturulmaya çalışılmıştır.

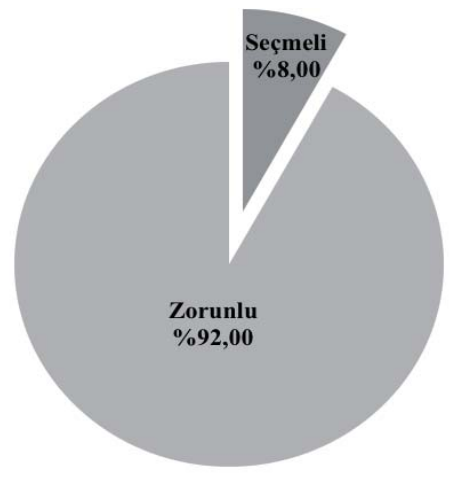

\section{Şekil 1. Dersin Zorunlu/Seçmeli Olması Gerekliliği Görüşü}

Katılımcıların tamamı(\%100) dersin öğretmen yetiştirme programlarında olması gerektiğ $i$ görüşündedir.

Ayrıca "Dersin Zorunlu/Seçmeli Olmas1 Gerekliliği Görüşü” grafiği incelendiğinde okul öncesi öğretmen adaylarının görüşlerinde, katılımcıların ikisi(\%8) dersin öğretmen yetiştirme programlarında seçmeli olması gerektiği görüşündeyken, geri kalan katılımcılar(\%92) ise dersin programlarda zorunlu olarak yer alması gerektiği görüşünü dile getirmektedir.

\section{Seçmeli Ders Olarak Kalmalı Fikri}

Dersin programda seçmeli olarak yer alması gerektiği görüşünü dile getiren katılımcıların (2K: \%8) bu gerekçelerinin üç ana başlık halinde toplanabileceği düşünülmektedir. Bu başlıklar frekans sırasına (sıklığı çok olandan az olana) göre şu şekildedir(Şekil 2):

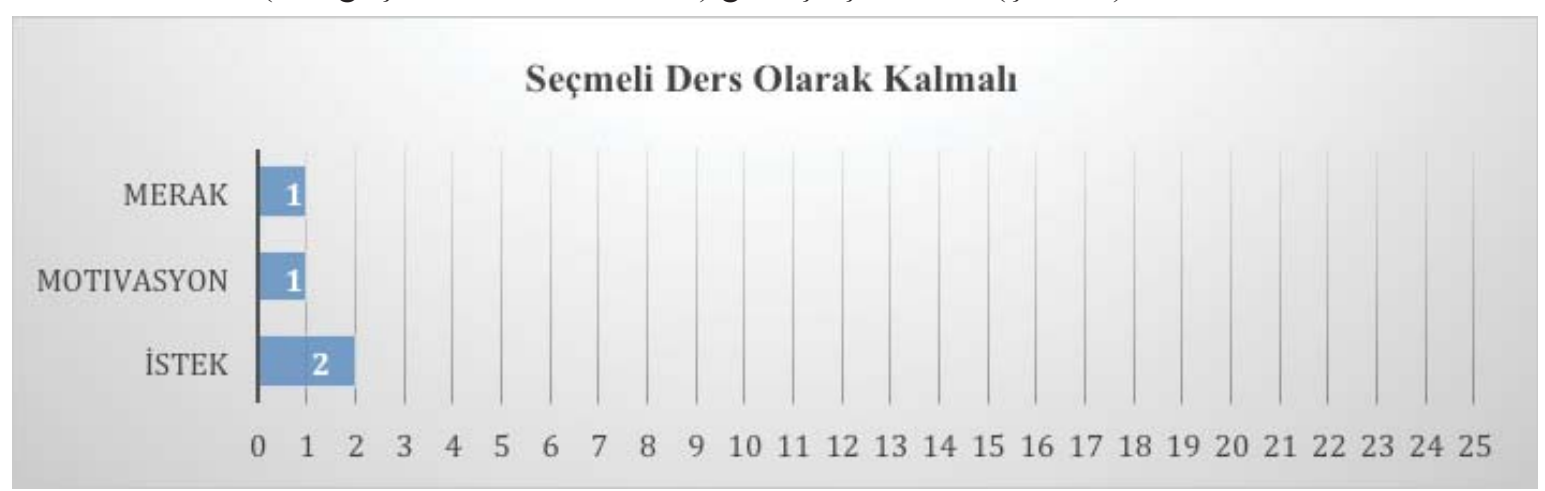

Şekil 2. Seçmeli Ders Olarak Kalmasını İsteyen Katılımcıların Frekansları 


\section{Merak}

Dersin seçmeli olarak kalması gerekliliğini savunan katılımcı 913, merak başlığı altında "Mesela çoğu insan var tarihe meraklı olmayan...O yüzden seçmeli kalması daha iyi." şeklinde kendini ifade etmiş ve merakı olmayan öğretmen adaylarının derse katılmamasının daha iyi olacağını fikrini savunmuştur.

\section{Motivasyon}

Yine seçmeli olarak kalmasını savunan katılımcı ise "Bu dersi seçenlerin belli bir yaşantısı, kafa düzeyi var. Çok alakasız birinin bu dersi zorla alıp dersin huzurunu bozmasina ben katlanamam. Dersin huzurunu bozmasa bile bu benim motivasyonumu düşürür(K-919). ” demektedir.

\section{İstek}

Dersin seçmeli kalması gerektiğini savunan iki katılımeı da derse isteksiz giren öğretmen adaylarının dersin kalitesini ve öğrenme düzeylerini düşüneceği düşünmektedirler. Ders zorunlu olursa bu isteksizliğin süreci olumsuz etkileyeceği fikrindedirler. Bu durumu da şu tümcelerle belirtmişlerdir; "Bu dersi seçenlerin belli bir yaşantısı, kafa düzeyi var. Çok alakasız birinin bu dersi zorla alıp dersin huzurunu bozmasina ben katlanamam. Dersin huzurunu bozmasa bile bu benim motivasyonumu düşürür(K-919).”, “...tarihe meraklı olmayan, çok sikılan. Seçmek istemeyebilirler... (K.913)”.

Dersin seçmeli olmasını isteyen katılımcılar; zorunlu ders olması durumunda dersi almak istemeyen ya da önem vermeyen kişilerin derse geldikleri için dersin ahengini olumsuz yönde etkileyebileceklerini ifade etmişlerdir. Seçmeli derslerde hem öğrenmenin hem de öğrenenin olumlu sonuçlara ulaştığı görüşüne sahip oldukları ifade edilebilir. $\mathrm{Bu}$ nedenle müze eğitimi dersinin fakültelerde seçmeli olarak bulunması gerektiği görüşünü dile getirmişlerdir.

\section{Zorunlu Ders Olması Gerekir Fikri}

Dersin programda zorunlu olarak yer alması gerektiği görüşünü dile getiren katılımcıların(23K:\%92) ise bu gerekçelerinin dörtana başlık halinde toplanabileceğidüşünülmektedir. Bu başlıklar frekans sırasına(sıklığı çok olandan az olana)göre mesleki gelişim/katkı, etkili öğrenme, firsat eşitliği, farkındalık gelişimi şeklindedir(Şekil 3).

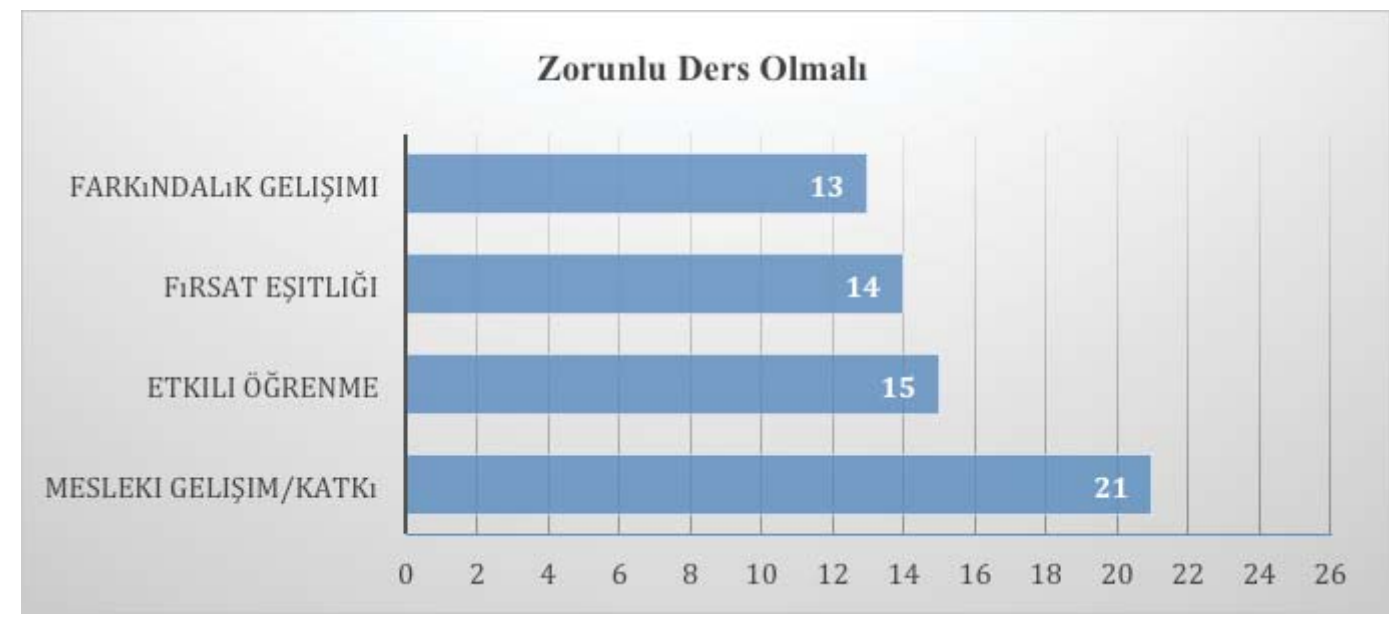

Şekil 3. Zorunlu Ders Olmasını İsteyen Katılımcıların Frekansları 


\section{Mesleki Gelişim Katkı}

Mesleki gelişimlerine katkı sağlaması nedeniyle dersin zorunlu olması gerektiğini düşünen 21 katılımcıların bazılarının bu görüşü destekler nitelikteki tümceleri şu şekildedir. "Bu ders tabi ki zorunlu olmall. Nasıl böyle bir eksiklik seçime bırakllabilir anlayamıyorum. (K-922).”, “Müze eğitimi bence her öğretmenin almasl gereken bir eğitim çünkü müzede boş boş gezmenin hiçbir anlamı yok. Bence bütün ögrretmenlerin, okul öncesi ögretmenlerinin sinıf ögretmenlerinin alması gereken bir eğitim(K-904)”, "Ben şanslı kişilerden olduğumu düşünüyorum. Dersi alabilmek için hangi sıkıntılı aşamalardan geçtiğimi anlattım yani. Zaten alelade bir ders olsaydı yani hiçbir derste bu kadar...bu da doğru bir tabir olmadı ama hani daha ey bir ders olsaydı Benim adıma keşke zorunlu olsaydl.(K-905).

\section{Etkili Öğrenme}

Etkili ögrenme başlı̆̆ altında zorunlu olması gerekliliğini dile getiren 15 katılımcılardan bazılarının tümceleri ise; "Hazırlıkla beraber beş yıldır üniversite hayatında hangi ders aklında kaldı deseler ben kesinlikle müze eğitimi derim. Böyle bir dersin o yüzden seçmeli olmasına ben anlam veremiyorum. Keşke zorunlu olsaydı da diğer arkadaşlarımda alabilseydi seçmedikleri için çok pişman oldular(K-901).”, “...bu ders seçmeli olmasaydı zorunlu olsaydı. ... Biz yaşadıklarımızı onlara(dersi almayanlara) anlattık ama ne kadar anladılar, algılayabildiler orası soru işareti(K-920). şeklindedir.

\section{Fırsat Eşitliği}

Zorunlu olması gerekliliği diğer öğretmen adaylarıyla firsat eşitliğine bağlayan 14 katılımcıdan bazılarının tümceleri ise şu şekildedir; "Bence seçimlik olmasının avantajı şu daha az insanla yapıyorsunuz. Ama ben bunu herkesin ögrenmesini isterim. Çünkü çok farklı bir vizyon geliştiriyor insanda. Yani belki sen müze eğitimi dersi almadan bunu sürece katmayı düşünebilirsin ama bunu yalnızca idealist ögretmenler yapacak ve ĕger ki müze ĕgitimi dersi zorunlu alırsa diğer ögretmen adayları da idealist bir öğretmene daha çok yaklaşacak (K-898)”, "Arkadaşlarımdan +1 önde olduğumu düşünüyorum. Bunlardan yola çıkarsak herkesin eşit seviyede eğitim alması için bence zorunlu olmall. (K-921)”.

\section{Farkındalık Gelişimi}

Dersin zorunlu olması gerektiğini düşünen 13 öğretmen adayı kendi farkındalıklarının ve arkadaşlarının, öğrencilerinin farkındalık durumlarının gelişmesi gerekliliğini savunmaktadırlar. Bu doğrultuda katılımcıların bazı tümceleri şunlardır; "Müze eğitimi zorunlu olmalı. Seçmeli olmamalı öyle olunca kaç kişi seçecek ki? Yine devam edecek çocuklar böyle baklp bakıp gidecek müzeye hiçbir şeyin anlamı kalmayacak yani. Kaç öğretmen alacak ki müze eğitimini bilen? O yüzden seçmeli olmamasından yanayım. Kesinlikle zorunlu olmalı(K-908)”, "Bence okul öncesi eğitimde en başta olması gereken derslerden birisi. Benim hiçbir eğitimim yoktu ve süreç sonunda gerçekten bir sürü şey ögrendim. (K-904)”, “Zorunlu olmalı kesinlikle seçmeli olmamalı. Şu an bile benim dersi almayan kişilerden farklı olduğumu düşünüyorum. Onların bir kayıp yaşadı̆̆ını düşünüyorum. Yarın öbür gün meslek hayatlarında da aslında herkes böyle bir şey yapsa çok farklı bir durumda oluruz. Bir farkım olduğunu, fark kattığımı da düşünüyorum bu dersi alarak (K-903)”.

Dersin zorunlu olmasını isteyen katılımcılar; dersin öğretim yaşamında yaratacağ ayrıcalıklardan, eğlenceli öğrenme ortamından, yapılandırmacılık gibi çağdaş yaklaşımları merkeze 
almasından, mesleki ve kişisel katkılarından vb. kazanımlarından yola çıkarak bu çalışmaları her öğretmen adayının alması gerekliliğini dile getirmişlerdir.

Yukarıda belirtilen bulguların sonucunda ortaya çıkan başlıklardan da anlaşılacağı gibi 25 katılımcının büyük bölümü (23K) dersin zorunlu olması gerektiğini savunmaktadır. Sadece iki katılımcı bu noktada seçmeli olarak var olmasının daha anlamlı olacağı görüşündedir.

Özellikle katılımcıların bu görüşleri yaygınlık noktasında değerlendirildiğinde; fakültelerde zorunlu olarak tüm öğretmen adaylarının dersi alması sağlanırsa müzelerin, kültür, sanat ve bilimin merkezi haline gelecekleri, alternatif öğrenme mekanları olarak daha da işlevsel hale geleceklerini ortaya koymaktadır.

\section{Tartışma, Sonuç ve Öneriler}

Okul öncesi öğretmenleri öğretim programlarının içinde çeşitli müze ve galeri gezileri yapmaktadır. Ancak fakültelerde devam ettikleri öğretmenlik programlarında müze eğitimi dersi yoktur. Bazı üniversitelerde seçmeli ders olarak verilse de genele bakıldığında sayısının yaygınlık açısından yetersiz kaldığı ifade edilebilir. Bu noktada alan yazında öğretmen adaylarının lisans programında müze dersi almaları gerekliliğinin altı çizilmiştir. Örneğin Koçak (2010), "Öğretmenler, özel bir uzmanlı ĕgitiminden geçirilmelidir. Bu şekilde öğretmenlere müzelerin ve buralarda bulunan materyallerin ĕgitim sürecinde nasıl kullanılabileceğine yönelik bilgi ve beceriler kazandırılmalıdır." Aynı şekilde Ata (2002) da doğrudan okul öncesi öğretmenlerine yönelik bu önerisini dile getirmese de çalıştığı grup açısından sosyal bilgiler öğretmenlerinin bu dersi lisans programlarında almasını hatta diğer bölümlerde de bu gerekliliğin olduğunu belirtmiştir. Bunun yanında çağdaş yaklaşımlardan biri olan yapılandırmacılık ile günümüz Türkiye'sindeki öğretim programları şekillendirilmektedir. Bunun üzerine çalışan Şar ve Sağkol (2013) ise müze eğitimi dersinin öğretmenlik lisans programlarında gerekliliğinden ve bunun yapılandırmacılığa olan katkısından bahsetmektedir. Özellikle müze aktiviteleri, müze gezisine hazırlık ve bu doğrultuda öğrenciyi eğitmek gibi gerekli konuların kur tanımında yer alacağı bir “Müze Eğitimi” dersine eğitim fakültelerinde ihtiyaç olduğunun altını çizmektedirler.

$\mathrm{Bu}$ araştırmada dile getirildiği ve benzer araştırmalarda da belirtildiği gibi müze eğitimi dersinin öğretmenlik lisans programlarında gerekliliği açıkça görülmektedir. Öğretmen adaylarıyla yapılan görüşmelerden elde edilen bulgularla “Seçmeli Müze Eğitimi” dersinin kesinlikle öğretmenlik programlarında gerekli olduğunu belirtmişlerdir. Bunun yanında dersin seçmeli mi yoksa zorunlu mu olması gerektiği konusunda görüş birliği sağlanamamıştır.

Tüm katılımcıların \%8'ini oluşturan iki katılımcı, dersin seçmeli olması yönünde fikir beyan etmiştir. Özellikle istekli bir grupla bu tip çalışmaların daha anlamlı ve kalıcı öğrenmeyi sağladığını belirtmişlerdir. Katılımcıların bu görüşünden hareketle hem daha rahat öğretimin gerçekleşmesi hem de motivasyona dayalı öğretimin gerçekleşmesi için seçmeli ders anlayışının bu ders için daha uygun olduğu görüşü ortaya çıkmaktadır. Bu durumdan anlaşılmaktadır ki katılımcıların, dersin seçmeli olmasını isteme sebeplerinde; nitelikli eğitim arayışı fikri ön plana çıkmaktadır.

Toplam katılımcıların \%92'sini temsil eden yirmi üç katılımcı dersin zorunlu olması yönünde fikir beyan etmiştir. Özellikle bu dersi almış olmanın kendileriyle diğer arkadaşları arasında fark yaratacağını ve onların öğretmenliklerinin kendilerine göre eksik kalabileceğini öne çıkartan 
katılımcılar; eğitim fakültelerde verilen eğitimin genel anlamda daha nitelikli olması için bu dersin zorunlu olması gerekliliğini dile getirmişlerdir. Katılımcıların büyük bölümünün müze eğitiminin zorunlu bir ders olarak lisans programında yer almasını istemeleri güzel bir istek gibi görünse de dersi yürütebilecek nitelikte öğretim elemanı yetersizliği bu isteği gerçekleşebilir olmaktan uzaklaştıran bir etkendir. Dersin zorunlu olması durumunda müze eğitimi konusunda yetişmiş/kalifiye öğretim elemanı azlığı sorun olarak düşünülse de araştırmanın sınırlılıkları içinde yer almaması sebebiyle bu konudaki tartışma başka bir araştırmanın konusu içinde düşünülmektedir.

Sonuç olarak; araştırmanın amacına ulaştığı ve ortaya konan verilerde tüm katılımcıların görüşlerinin yer aldığı görülmüştür. Tüm katılımcıların müze eğitimi dersinin gerekliliği konusunda hem fikir olduğu net $(\% 100)$ olarak ortaya konmuştur. Diğer yandan genel görüşe bakıldığında \%92 gibi oranla katılımcıların büyük bir kısmı müze eğitimi dersinin okul öncesi öğretmenliği programında zorunlu olarak yer almasının gerekliliğini belirtmiştir.

Araştırmadan çıkan sonuçlar 1şığında şu önerilere ulaşılabilir.

1. Müze eğitimi dersinin okul öncesi öğretmenliği programında yer almasının uygun olacağı düşünülmektedir. Alanla ilgili çalışmalar YÖK ve üniversiteler tarafindan çoğaltılarak bu konuda akademik alt yapı oluşturulabilir.

2. Dersin zorunlu ya da seçmeli olmasının ise ancak mevcut üniversitelerin öğretim elemanı kadrolarının yeterliliğinin sorgulanmasıyla gerçekleşebileceği düşünülmektedir. $\mathrm{Bu}$ nedenle müze eğitimi alanında yetkin akademik kadrolar yetiştirilebilir.

3. Öğrencilerin/öğretmen adaylarının yer aldığı projelerin çoğaltılması için eğitim fakültelerinde bu tür çalışmalara öncelik verilebilir. 


\section{Kaynakça}

Abacı, O. (2003). Müze ve eğitim. K. Tezcan Akmehmet (Ed.) Eğitim ortamlarl olarak müzeler, İstanbul: T.C. Yıldız Teknik Üniversitesi Sanat ve Tasarım Fakültesi Yayını.

Abacı, O. (2008). Eğitimde müzelerden yararlanma. Muradiye Eğitim-Kültür-Sanat Dergisi, 4 (16), 58-65.

Adıgüzel, H. Ö. (2000). Eğitim bilimlerinde (Güzel Sanatlar Eğitiminde) bir uzmanlık alanı olarak kültür pedagojisi, Yayımlanmamış doktora tezi, Anakara Üniversitesi, Ankara.

Adıgüzel, H. Ö. (2004). Müzede eğitim ve drama. Abece dergisi, 212, 10-12.

Adıgüzel, Ö. (2006a). Bir öğrenme ortamı olarak müzeler, müze pedagojisi ve toplum ilişkisi. Çağdaş Eğitim Dergisi, Aralık, Ankara.

Adıgüzel, H. Ö. (2006b). Okul dışında farklı bir iletişim ve öğrenme ortamı olarak çocuk müzeleri. Eğitim Bilim ve Toplum Dergisi, 4(14), 32-41, Ankara.

Akmehmet Tezcan, K., \& Ödekan, A. (2006). Müze eğitiminin tarihsel gelişimi. İstanbul Teknik Üniversitesi Sosyal Bilimler Dergisi, 3(1), 47-58.

Akmehmet, T. K., (2001). Müzelerin sosyal bilimler öğretiminde laboratuvar olarak kullanılması ve okul-müze işbirliği. Sosyal Bilimler Öğretiminde Alternatif Teknik ve Yöntemler, Sosyal Bilimler Sempozyumu (24 Mart 2001). İstanbul: Eyüboğlu Eğitim Kurumları Yay. No:4, 116-123.

Akmehmet, T. K., (2007). Müzelerin eğitim amaçlı kullanım projesi. Eğitim ve Müze Semineri, (Ed. San, İnci, 2008), Kök Yayınları, 175-188

Ata, B. (2002). Müzelerle ve tarihî mekânlarla tarih öğretimi. Yayımlanmamış doktora tezi, Gazi Üniversitesi, Ankara.

Creswell, J.W. (2013). Araştırma deseni. (Ed. S.Beşir Demir,Çev.). Ankara: Eğiten Kitap

Çınkır, Ş., \& Demirkasımoğlu, N. (2015). Bilimsel araştırma yöntemleri gerçek dünya araş̧ırması. Ş. Çınkır ve N. Demirkasımoğlu (Çev. Ed.) Ankara: Anı Yayıncılık.

Eğitmen, A. (1995). Arkeoloji müzelerinin eğitim ortamı olarak etkinliğinin arttırılmasında yaratıcı dramanın yeri ve önemi. Yayımlanmamış yüksek lisans tezi. Ankara Üniversitesi, Ankara.

Eğitmen, A. (2007). Ankara Etnografya Müzesi’nde “Anadolu’da Üreten Kadın” temasına yaratıcı drama yöntemiyle bakış. Eğitim ve Müze Semineri, (Ed. San, İnci, 2008), Kök Yayınları, 131-146.

Erem, E. (2015). Görsel sanatlar eğitimi ve drama. Okul öncesinden ilköğretime kuramdan uygulamaya drama (Ed. Erdoğan, Tolga). Ankara: Eğiten Kitap.

Karasar, N. (1999). Bilimsel araştırma yöntemi. Ankara: Nobel Yayın Dağıtım.

Koçak, S. K. (2010). İlköğretim görsel sanatlar eğitimi dersindeki müze etkinliklerine yönelik, öğrenci, öğretmen ve müze yetkililerinin görüşleri, Yayımlanmamış yüksek lisans tezi, Gazi Üniversitesi, Ankara.

Okvuran, A. (2010). Çocuk müzeleri ve müzelerde yaratıı drama eğitimi, Çocuk Müzeleri ve Yaratıcı Drama. (Ed. San, İnci, 2012), Naturel Yayınc1lik. 43-55

San, İ. (1985). Sanat ve eğitimi. Ankara: Ütopya Yayınevi.

San, İ. (Ed.) (2008). Eğitim ve müze semineri. Ankara: Kök Yayıncılık.

Sönmez, V., \& Alacapınar, F. G. (2011). Örneklendirilmiş bilimsel araştırma yöntemleri. Ankara: Anı yayınları.

Şahin, Ş. (2007). Proje tabanlı ve disiplinlerarası gerçekleştirilen müzede eğitim uygulamalarından bir seçki. Eğitim ve Müze Semineri, (Ed. San, İnci, 2008), Kök Yayınları, 121-130.

Şar, E., \& Sağkol, T. (2013). Eğitim fakültelerinde müze eğitimi dersi gerekliliği üzerine. Hasan Ali Yücel Eğitim Fakültesi Dergisi, $10(2)$, 83-90.

Şimşek, H., \& Yıldırım, A. (2011). Sosyal bilimlerde nitel araştırma yöntemleri. Ankara: Seçkin Yayıncılık

Uzuner, Y. (1999). Niteliksel araştırma yöntemlerinin özellikleri. IV. Ulusal Eğitim Bilimleri Kongresi Bildirileri 3 Anadolu Üniversitesi Yayınlarl, 1076, 51 428- 439.

Terwiel, C. D. (2007). Sanat eğitiminde bir yöntem olarak müzelerden yararlanma. Eğitim ve Müze Semineri, (Ed. San, Inci, 2008), Kök Yayınlarl, 147-155 